Research Article

\title{
Assessing the efficacy and safety of pitavastatin compared to atorvastatin in dyslipidemic patients: a double blind randomized controlled trial
}

\author{
Chetan Y. Patil*, Mirza Shiraz Baig, Sudhkar M. Doifode
}

Department of Pharmacology, Government Medical College and Hospital, Aurangabad431001, Maharashtra, India

Received: 03 March 2016 Accepted: 04 April 2016

*Correspondence to: Dr. Chetan Y. Patil, Email: drchetanpatil.gmc @ gmail.com

Copyright: (C) the author(s), publisher and licensee Medip Academy. This is an openaccess article distributed under the terms of the Creative Commons Attribution NonCommercial License, which permits unrestricted noncommercial use, distribution, and reproduction in any medium, provided the original work is properly cited.

\begin{abstract}
Background: Statins are the first choice in the treatment of dyslipidemia, commonly atorvastatin. Pitavastatin is a newer statin with more potency, less drug interactions and many added advantages considering the longevity of treatment required for dyslipidemia. The objective of this study was to evaluate the efficacy and safety of pitavastatin versus atorvastatin in dyslipidemic patients associated with hypertension, diabetes and/or coronary artery disease. Methods: A prospective, comparative, randomized, controlled, double blind, clinical trial was designed. Total 100 eligible subjects were randomised into 1:1 ratio to receive pitavastatin $4 \mathrm{mg}$ once daily and atorvastatin $20 \mathrm{mg}$ once daily for period of 8 weeks. Evaluation was scheduled at 4 week and 8 week. The efficacy assessment included percentage change from baseline in various lipid parameters like low density lipoprotein cholesterol (LDLC), total cholesterol (TC), high density lipoprotein cholesterol (HDLC), triglycerides (TG), and LDLC/HDLC ratio.

Results: Analysis of data showed a significant improvement in all lipid parameters within both therapeutic groups. The difference in LDLC, TC and TG levels was not statistically significant between the two treatment groups after 8 weeks of therapy. However, significant improvement was seen in HDLC and LDLC/HDLC ratio with pitavastatin as compared to atorvastatin at the end of the study. Both were well tolerated.

Conclusions: With better HDLC levels, in addition to comparable efficacy and good tolerability of pitavastatin, as compared to atorvastatin, could be considered as good alternative for treatment of dyslipidemia.
\end{abstract}

Keywords: Dyslipidemia, Pitavastatin, Atorvastatin

\section{INTRODUCTION}

Statins are currently the most effective drugs for lowering LDLC and represent the first choice in the treatment of dyslipidemia. ${ }^{1}$ They are reversible competitive inhibitors of HMG-CoA reductase, which is the rate-limiting step for cholesterol biosynthesis. Statin therapy is now routinely recommended for the prevention of cardiovascular diseases in patients with or without type 2 diabetes mellitus based on convincing evidence of reductions in mortality and vascular events in major clinical outcome trials. ${ }^{2-4}$
Hyperlipidemia is a major cause of atherosclerosis and atherosclerosis-induced conditions, such as coronary heart disease (CHD), ischemic cerebrovascular disease and peripheral vascular disease. ${ }^{5}$ Cardiovascular disease (CVD) related to atherosclerosis of the arterial vessel wall and thrombosis remains a leading cause of morbidity and mortality in world. ${ }^{6,7}$ Worldwide, an estimated 17.3 million CVD-related deaths were predominantly due to CHD and stroke occurred in 2008 and it is expected to rise to almost 23.6 million deaths per year by 2030 . $^{6}$

Patients with type II diabetes mellitus are usually dyslipidemic, even when under relatively good glycaemic control. Furthermore type 2 diabetes is an important risk 
factor for atherosclerosis leading to cardiovascular diseases, which with superimposed dyslipidemia may increase this risk. $^{8}$

Pitavastatin, the latest addition to the statin group is a chemically synthesized statin. ${ }^{9}$ It is approved by the food and drug administration USA in August 2009. ${ }^{10}$ A unique feature of this HMG-CoA reductase inhibitor is the cyclopropyl group that can bind with high affinity to the hydrophobic regions of $\mathrm{HMG}-\mathrm{CoA}$ reductase $(\mathrm{Ki} 1.7$ $\mathrm{nmol} / \mathrm{L}$ ); it is this feature that is thought to provide enhanced potency of this drug. ${ }^{11,12}$ Pitavastatin inhibits HMG-CoA reductase in a dose dependent fashion and with greater potency than simvastatin or pravastatin (concentration needed to inhibit 50\% of HMG-CoA reductase activity $\left(\mathrm{IC}_{50}\right) \quad 6.8$ versus. 16 and 46 $\mathrm{nmol} / \mathrm{L}){ }^{11,13}$ It also acts to improve the lipid profile by inducing LDL receptor expression. ${ }^{14-16}$ In contrast to other statins, it undergoes limited metabolism by cytochrome P450 (CYP) isoenzymes (CYP2C9 and, to a lesser extent, CYP2C8), and hence, the potential for interactions with drugs metabolized by these enzymes is low. Pitavastatin is currently indicated for patients with primary hyperlipidemia and mixed dyslipidemia..$^{10,17}$

Atorvastatin, a lipophilic statin, was approved by the US food and drug administration on December 17, 1996. Like other such agents, it inhibits the action of HMGCoA reductase and thereby decreases endogenous cholesterol synthesis, leading to a decrease in circulating low-density lipoprotein cholesterol. ${ }^{18,19}$ Currently, it is the most widely prescribed statin in the world. ${ }^{20-22}$ It is currently undergoing worldwide clinical development and so far more than 500 randomised control trials to evaluate atorvastatin efficacy and safety have been conducted. ${ }^{19,23,24}$ With this background information and the trends of using statins in practice present study was planned to evaluate and compare the efficacy and safety of newer pitavastatin $(4 \mathrm{mg})$ and routinely prescribed atorvastatin $(20 \mathrm{mg})$ for the treatment of dyslipidemia.

\section{METHODS}

The 8 week prospective, randomized, double-blind, single centre, parallel group study was conducted in a tertiary care hospital in India, where patients attending the medicine outpatient department or diabetes clinic were recruited for the study. Approval of the institutional ethics committee was taken prior to the conduct of the study (Pharma/IEC-GMCA/569/2011-17/12/2011). Study was conducted from December 2012 to December 2013.

Patients of either sex between 35-65 years suffering from dyslipidemia according to NCEP ATP III guidelines (national cholesterol education program, adult treatment panel III) (LDLC $\geq 130 \mathrm{mg} / \mathrm{dl}, \mathrm{TC} \geq 240 \mathrm{mg} / \mathrm{dl}$ ) associated with hypertension, diabetes and/coronary artery disease, and those ready to give written informed consent were included in the study. Informed written consent was obtained from all subjects prior to recruitment.
Exclusion criteria were pregnancy and lactating mother, history of muscular or neuromuscular disease of any type or drug allergy to study drugs or chronic liver and kidney diseases, concomitant medications such cyclosporine A, gemfibrozil, clarithromycin, rafamycin, rifampicin etc, serum total creatine kinase (CPK) more 5 times of normal, history of HIV infection, alcohol addiction or having exposure to any investigational new drug within 30 days of study entry.

The study was performed under double-blind conditions. Simple randomization was done in 1:1 ratio on the basis of a computer generated random number list and allocation was concealed till the point of completion of the study using serially numbered opaque sealed envelopes. After enrolling the subjects, each received one treatment pouch and asked to take study medication once a daily before meal in the evening for 8 weeks. All subjects were asked to come for follow up weekly in the OPD until the study has been completed, in order to ensure compliance and record any adverse drug reaction occurring in between the OPD visits, if not reported by patients spontaneously.

Standard therapies for underlying disease as received by the subjects before enrollment were allowed to continue without any changes. All the subjects were made to undergo baseline investigations after enrolment (day 0 ). The investigations were repeated at 4 week and at the end of the study, 8 week. The investigations such as lipid profile (LDLC, HDLC, VLDLC, TC and TG), blood glucose level, hematological parameters ( $\mathrm{Hb}, \mathrm{CBC}, \mathrm{DLC}$, and ESR.) and serological parameters (AST, ALT, serum proteins, $\mathrm{A} / \mathrm{G}$ ratio, serum bilirubin, blood urea nitrogen (BUN), serum creatinine and serum CPK) were done during the study period.

The primary efficacy end-point was percentage change in baseline LDLC level. The secondary efficacy end points were.

- Percentage change in baseline TC level.

- Percentage change in baseline TG level.

- Percentage change in baseline HDLC level.

- Percentage change in baseline LDLC/HDLC ratio.

Safety was assessed in terms of the rate of occurrence of adverse events. All the patients were properly informed about the possible adverse drug reaction associated with use of study drugs. Any adverse event that occurred was evaluated and recorded in case record form stating the onset, severity, duration, likely cause, action taken with reference to the study drugs. Safety was also assessed by evaluating the haematological and serological investigations. Sample size was calculated on the basis of the primary outcome measure. It was estimated that 50 subjects would be required per group in order to detect $40 \%$ reduction in LDLC levels at the end of study from baseline with $80 \%$ power and $5 \%$ probability of type I error. The modified intention-to-treat approach was used 
for all efficacy analyses. Only patients who had taken all the doses of the study drugs and had post-treatment assessment were included in the analysis. Data were captured on structured case report forms and statistical analysis was carried out using repeated measures ANOVA test for comparing numerical variables within the study group at baseline, 4 week and 8 week. For comparing numerical variables between the study groups after therapy, unpaired 't' test was applied. Fisher's exact test or Chi-square test with 2-tailed ' $\mathrm{P}$ ' value was employed for intergroup comparison of categorical variables depending upon the type of data. The raw data was entered into a Microsoft Excel spread sheet and analysed by GraphPad Prism version 5 (San Diego, California: GraphPad Software Inc., 2007) statistical software.

\section{RESULTS}

All the subjects enrolled in the study completed the treatment and were analysed after completion of study. After completion of study period decoding of treatment received by study participants was done. The baseline characteristics of the patients like age, sex, BMI, associated disease conditions and treatments receiving for them were comparable between groups (Table 1).

Table 1: Baseline characteristics.

\begin{tabular}{|c|c|c|c|}
\hline Parameter & $\begin{array}{l}\text { Pitavastatin } \\
\quad(n=50)\end{array}$ & $\begin{array}{l}\text { Atorvastatin } \\
\qquad(\mathbf{n}=\mathbf{5 0})\end{array}$ & $\begin{array}{l}{ }^{6} \mathbf{P} \\
\text { value }\end{array}$ \\
\hline $\begin{array}{l}\text { Age (years) } \\
\text { Mean(SD) }\end{array}$ & $59.36(3.76)$ & $59.48(3.85)$ & 0.94 \\
\hline Sex $M: F$ & $26: 24$ & $25: 25$ & 1.00 \\
\hline $\begin{array}{l}\text { BMI }(\mathrm{kg} / \mathrm{m} 2) \\
\text { Mean(SD) }\end{array}$ & $26.41(1.75)$ & $26.86(1.32)$ & 0.16 \\
\hline \multicolumn{4}{|c|}{ Primary Condition } \\
\hline Diabetes & $25(50 \%)$ & $23(46 \%)$ & \multirow{3}{*}{0.68} \\
\hline $\begin{array}{l}\text { Essential } \\
\text { Hypertension }\end{array}$ & $14(28 \%)$ & $18(36 \%)$ & \\
\hline $\begin{array}{l}\text { Coronary } \\
\text { artery disease }\end{array}$ & $11(22 \%)$ & $9(18 \%)$ & \\
\hline
\end{tabular}

Value: Mean (SD); SD, standard deviation; M, male; F, female; BMI, body mass index.

Table 2: Mean changes in LDLC level.

\begin{tabular}{|c|c|c|c|}
\hline Assessment & $\begin{array}{l}\text { Pitavastatin } \\
(\mathrm{n}=50)\end{array}$ & $\begin{array}{l}\text { Atorvastatin } \\
(\mathrm{n}=50)\end{array}$ & $\begin{array}{l}\text { Intergroup } \\
\text { ' } \mathbf{P} \text { ' value }\end{array}$ \\
\hline Baseline & $163.6(5.12)$ & $161.6(10.66)$ & 0.26 \\
\hline 4 week & $100.3(5.18)$ & $101.0(11.77)$ & 0.69 \\
\hline 8 week & $93.26(4.16)$ & $94.14(10.99)$ & 0.60 \\
\hline $\begin{array}{l}\text { Intragro } \\
\text { up P } \\
\text { value }\end{array}$ & $<0.001$ & $<0.001$ & \\
\hline \multicolumn{4}{|c|}{ Mean $\%$ change at day 56 from baseline } \\
\hline & $-42.98 \%$ & $-41.76 \%$ & \\
\hline
\end{tabular}

Value: Mean (SD); SD, standard deviation.
The primary efficacy end-point, percentage change in baseline LDLC level at the end of the study (Table 2) showed significant reduction within both groups, but no statistical difference was found between two groups.

Table 3: Mean changes in TC level.

\begin{tabular}{|c|c|c|c|}
\hline Assessment & $\begin{array}{l}\text { Pitavastatin } \\
(n=50)\end{array}$ & $\begin{array}{l}\text { Atorvastati } \\
n(n=50)\end{array}$ & $\begin{array}{l}\text { Intergroup } \\
\text { ' } \mathbf{P} \text { ' value }\end{array}$ \\
\hline Baseline & $261.0(9.21)$ & $259.2(8.61)$ & 0.30 \\
\hline 4 week & $192.2(8.05)$ & $190.7(10.31)$ & 0.44 \\
\hline 8 week & $185.1(7.40)$ & $183.2(9.89)$ & 0.27 \\
\hline $\begin{array}{l}\text { Intragroup } \\
\mathrm{P} \text { value }\end{array}$ & $<0.001$ & $<0.001$ & \\
\hline \multicolumn{4}{|c|}{ Mean $\%$ change at day 56 from baseline } \\
\hline & $-29.08 \%$ & $-29.32 \%$ & \\
\hline
\end{tabular}

Value: Mean (SD); SD, standard deviation.

Table 4: Mean changes in TG level.

\begin{tabular}{|c|c|c|c|}
\hline Assessment & $\begin{array}{l}\text { Pitavastatin } \\
(n=50)\end{array}$ & $\begin{array}{l}\text { Atorvastati } \\
n(n=50)\end{array}$ & $\begin{array}{l}\text { Intergroup } \\
\text { ' } \mathbf{P} \text { ' value }\end{array}$ \\
\hline Baseline & $239.1(34.56)$ & $241.1(37.41)$ & 0.79 \\
\hline 4 week & $195.2(28.95)$ & $190.7(10.31)$ & 0.31 \\
\hline 8 week & $183.7(27.3)$ & $185.5(29.85)$ & 0.75 \\
\hline $\begin{array}{l}\text { Intragroup } \\
\mathrm{P} \text { value }\end{array}$ & $<0.001$ & $<0.001$ & \\
\hline \multicolumn{4}{|c|}{ Mean $\%$ change at day 56 from baseline } \\
\hline & $-23.18 \%$ & $-23.05 \%$ & \\
\hline
\end{tabular}

Value: Mean (SD); SD, standard deviation.

Table 5: Mean changes in HDLC level.

\begin{tabular}{|c|c|c|c|}
\hline Assessment & $\begin{array}{l}\text { Pitavastatin } \\
(n=50)\end{array}$ & $\begin{array}{l}\text { Atorvastati } \\
\mathbf{n}(\mathbf{n}=\mathbf{5 0})\end{array}$ & $\begin{array}{l}\text { Intergroup } \\
\text { ' } \mathbf{P} \text { ' value }\end{array}$ \\
\hline Day 0 & $49.66(4.07)$ & $49.32(3.05)$ & 0.64 \\
\hline Day 28 & $52.88(3.86)$ & $50.36(3.01)$ & $<0.001$ \\
\hline Day 56 & $55.12(4.25)$ & $51.96(3.18)$ & $<0.001$ \\
\hline $\begin{array}{l}\text { Intragroup } \\
\mathrm{P} \text { value }\end{array}$ & $<0.001$ & $<0.001$ & \\
\hline \multicolumn{4}{|c|}{ Mean $\%$ change at day 56 from baseline } \\
\hline & $+11.00 \%$ & $+5.35 \%$ & \\
\hline
\end{tabular}

Value: Mean (SD); SD, standard deviation.

Table 6: Mean changes in LDLC/HDLC ratio.

\begin{tabular}{|c|c|c|c|}
\hline Assessment & $\begin{array}{l}\text { Pitavastatin } \\
(n=50)\end{array}$ & $\begin{array}{l}\text { Atorvastati } \\
\mathrm{n}(\mathrm{n}=\mathbf{5 0})\end{array}$ & $\begin{array}{l}\text { Intergroup } \\
\text { ' } \mathbf{P} \text { ' value }\end{array}$ \\
\hline Day 0 & $3.32(0.30)$ & $3.30(0.35)$ & 0.76 \\
\hline Day 28 & $1.91(0.17)$ & $2.01(0.28)$ & 0.02 \\
\hline Day 56 & $1.70(0.15)$ & $1.82(0.26)$ & $<0.01$ \\
\hline $\begin{array}{l}\text { Intragroup } \\
\mathrm{P} \text { value }\end{array}$ & $<0.001$ & $<0.001$ & \\
\hline \multicolumn{4}{|c|}{ Mean $\%$ change at day 56 from baseline } \\
\hline & $-48.68 \%$ & $-44.71 \%$ & \\
\hline
\end{tabular}

Value: Mean (SD); SD, standard deviation. 
The secondary efficacy end-points that are percentage change in baseline TC level (Table 3) and TG level (Table 4) at the end of the study showed the significant reduction in levels within the groups also both groups were comparable at end of 8 week. However, percentage change in baseline HDLC level (Table 5) showed improvement by $11 \%$ from baseline in pitavastatin group as compared to $5.35 \%$ in atorvastatin group which was statistically significant favouring the pitavastatin $(\mathrm{P}<0.001)$. Likewise, LDLC/HDLC ratio (Table 6) showed improvement within both groups but pitavastatin showing statistically significant improvement over atorvastatin $(\mathrm{P}<0.01)$.

Safety parameters which includes laboratory parameters like haemoglobin, total WBC count, differential WBC count, platelet count, ESR, liver function tests (AST, ALT), Sr. Proteins, Sr. A/G ratio, blood sugar level, kidney function tests (Sr. creatinine, Sr. BUN) Sr. CPK were within the normal range in both groups. Occurrences of adverse events are shown in (Table 7).

Table 7: Adverse events.

\begin{tabular}{|c|c|c|c|}
\hline Parameter & $\begin{array}{l}\text { Pitavastatin } \\
(\mathbf{n}=50)\end{array}$ & $\begin{array}{l}\text { Atorvastatin } \\
(\mathbf{n}=\mathbf{5 0})\end{array}$ & $\begin{array}{l}P \\
\text { value }\end{array}$ \\
\hline \multirow[t]{3}{*}{$\begin{array}{l}\text { Overall } \\
\text { Incidence }\end{array}$} & $8(16 \%)$ & $10(20 \%)$ & 0.80 \\
\hline & 0 & 0 & \\
\hline & 0 & 0 & \\
\hline \multicolumn{4}{|l|}{ Common AE } \\
\hline Headache & 4 & 5 & \multirow{3}{*}{0.80} \\
\hline Myalgia & 2 & 3 & \\
\hline Back pain & 4 & 4 & \\
\hline Constipation & 2 & 1 & \\
\hline
\end{tabular}

$\mathrm{AE}$, adverse event

Both treatments were well tolerated throughout the study period. Adverse events were reported by $16 \%$ patients in pitavastatin group while $20 \%$ patients in atorvastatin group. Incidence of adverse event was more in atorvastatin $20 \%(10 / 50)$ than pitavastatin $16 \%(8 / 50)$. However difference was not statistically significant $(\mathrm{P}-$ 0.80). Adverse reactions include headache, myalgia, back pain, constipation, and diarrhoea, incidence of which not significant statistically in between groups. All events were of mild to moderate severity and settled spontaneously with or without separate treatment. It was not possible to link these adverse events conclusively to any of the study medications. None of the patients in both the treatment groups reported any serious adverse event or no patient discontinued the study drug due to adverse events.

\section{DISCUSSION}

Evidence has shown dyslipidemia (elevated LDLC, TC and TG levels and reduced HDLC) is a major cause of atherosclerosis and atherosclerosis- induced conditions, such as coronary heart disease (CHD), ischemic cerebrovascular disease and peripheral vascular disease. 5 Epidemiological investigations of human populations incriminate high levels of LDLC as being atherogenic. In population studies, the serum total cholesterol is a good surrogate for LDLC levels. The framingham heart study, the multiple risk factor intervention trial (MRFIT), and the lipid research clinics (LRC) trial, found a direct relationship between high levels of LDLC (or total cholesterol) or low levels of HDLC and the rate of newonset CHD in men and women who were initially free of CHD. ${ }^{25-28}$ The same relation holds for recurrent coronary events in people with established CHD. Any LDLC above $100 \mathrm{mg} / \mathrm{dL}$ appears to be atherogenic. ${ }^{1,29,30}$ Elevated LDLC is therefore identified as the primary target of lipid-lowering therapy as recommended by the NCEPATP III. ${ }^{1}$ Hence the identification and treatment of dyslipidemia is a high clinical priority in cardiovascular medicine. ${ }^{31,32}$ The HMG CoA reductase inhibitors are the most effective and practical class of drugs for reducing LDLC concentrations. ${ }^{1}$ Results from five clinical trials with a mean duration of 5.4 years have documented a decrease in CHD and total mortality, reductions in myocardial infarctions, revascularization procedures, stroke, and peripheral vascular disease. , $^{1,33-36}$

The present study evaluated and compared the efficacy and safety of recently approved pitavastatin $(4 \mathrm{mg})$ with atorvastatin $(20 \mathrm{mg})$ in patients with dyslipidemia associated with hypertension, diabetes and/or coronary artery diseases. The result of present study showed significant reduction in baseline LDLC level in both the study group, pitavastatin $42.98 \%$, Whereas atorvastatin $41.76 \%$ which were comparable. Similarly, reduction in baseline levels of TC (pitavastatin 29.08\% and atorvastatin 29.32\%) and TG (pitavastatin $23.18 \%$ and atorvastatin $23.05 \%$ ) was seen. These results are in accordance with those of Gumprecht et al, Ose et al, Eriksson et al, Budinski et al, Kawashiri MA et al, Nawrocki JW et al, Schrott $\mathrm{H}$ et al, Jones $\mathrm{P}$ et al, and Andrews TC et al. ${ }^{37-45}$

There was statistically significant improvement seen in HDLC level in present study in both the treatment group. Pitavastatin was associated with increase in baseline HDLC level up to $55.12(4.25) \mathrm{mg} / \mathrm{dl}$ at 8 weeks that is by $11.00 \%$ from baseline. While atorvastatin was associated with increase in baseline HDLC level up to 51.96 (3.18) $\mathrm{mg} / \mathrm{dl}$, that is by $5.35 \%$ at the end of study. However, statistically significant improvement was observed in pitavastatin as compared to atorvastatin receiving group at 4 week and 8 week ( $\mathrm{P}-<0.001$ and $<0.001$ respectively). Similarly, improvement in LDLC/HDLC ratio was seen with pitavastatin by $48.68 \%$ and atorvastatin $44.71 \%$ from the baseline. However, pitavastatin was associated with statistically significant reduction in LDLC/HDLC ratio as compared to atorvastatin at both 4 and 8 week (P-0.02 and $<0.01$ respectively). These results obtained in present study are in accordance with studies conducted by Kazumasa et al, Budinski et al, and Kawashiri MA et al, 
who reported significant increase in HDLC level with pitavastatin as compared to atorvastatin. ${ }^{40,41,46}$

As regards to safety of the study medications, adverse events were comparable in both groups; no serious adverse events were reported. No significant differences were seen between the groups in the laboratory tests.

\section{CONCLUSION}

Dyslipidemia is one of the major risk factors for the development of CVD and there is considerable evidence to demonstrate that reducing excess levels of LDLC and TC can prevent CVD. Moreover improvement in deranged HDLC level in CVD patients had a favourable outcome. Hence the identification and treatment of dyslipidemia is a high clinical priority in cardiovascular medicine.

In this study, pitavastatin $4 \mathrm{mg}$ was found to be eqiefficacious to atorvastatin $20 \mathrm{mg}$ in reducing the LDLC. Also, the effect of pitavastatin on TC level and TG levels did not differ from that of atorvastatin and both the treatments were equally efficacious. However pitavastatin increased HDLC level better than the atorvastatin and also LDLC/HDLC ratio was decreased more with pitavastatin than atorvastatin. With regards to safety both pitavastatin and atorvastatin were well tolerated throughout study period.

To conclude both pitavastatin and atorvastatin showed good and comparable efficacy and tolerability, with pitavastatin having significantly better improvement of HDLC levels. Therefore the newer pitavastatin could be considered as good alternative to atorvastatin in treatment of dyslipidemia.

\section{ACKNOWLEDGEMENTS}

The Author thankful to Department of Medicine and Department of Biochemistry GMC, Aurangabad, Maharashtra for their invaluable help in the completion of this project.

Funding: No funding sources Conflict of interest: None declared

Ethical approval: The study was approved by the Institutional Ethics Committee (Pharma/IECGMCA/569/2011-17/12/2011)

\section{REFERENCES}

1. Third report of the national cholesterol education program (NCEP) expert panel on detection, evaluation, and treatment of high blood cholesterol in adults (adult treatment panel III) final report. Available at http://www.nhlbi.nih.gov/guidelines/cholesterol/atp3f ull.pdf. Accessed 2 November 2012.
2. Kearney PM, Blackwell L, Collins R, Keech A, Simes J, Peto R, et al. Cholesterol treatment trialists' (CTT) collaborators, Efficacy of cholesterol-lowering therapy in 18,686 people with diabetes in 14 randomised trials of statins: a meta-analysis. Lancet. 2008;371(9607):117-25.

3. American diabetes association. Standards of medical care in diabetes. Diabetes Care. 2010;33(1):11-61.

4. Fruchart JC. Peroxisome proliferator-activated receptor alpha activation and high-density lipoprotein metabolism. Am J Cardiol. 2001;88(12):24-9.

5. Bersot TP. Drug therapy for hypercholesterolemia and dyslipidemia. In: Brunton LL, Chabner BA, Knollmann BC, editors. Goodman and Gilman's. The Pharmacological Basis of Therapeutics. $12^{\text {th }}$ ed. New York. McGraw-Hill Publications; 2011:877-908.

6. World health organisation. Cardiovascular diseases (CVDs). Available at URL: http://www.who.int/mediacentre/factsheets/fs317/en/i ndex.html. Accessed 31 October 2012.

7. Reiner Z, Catapano AL, De Backer G, Graham I, Taskinen MR, Wiklund $\mathrm{O}$, et al. ESC/EAS Guidelines for the management of dyslipidaemias: the task force for the management of dyslipidaemias of the European society of cardiology (ESC) and the European atherosclerosis society (EAS). Eur Heart J. 2011;32(14):1769-818.

8. Libby P. The pathogenesis, prevention, and treatment of atherosclerosis. In: Longo DL, Fausi AS, Kasper DL, Hauser SL, Jameson JL, Loscalzo J, editors. Harrison's Principles of Internal Medicine. $18^{\text {th }}$ ed. New York. McGraw-Hill Publications; 2012:1983-91.

9. Mukhtar RY, Reid J, Reckless JP. Pitavastatin. Int J Clin Pract. 2005;59(2):239-52.

10. Prescribing information of pitavastatin. Available at URLhttp://www.accessdata.fda.gov/drugsatfda_docs/ label/2009/02236 s000lbl.pdf. Accessed 2 November 2012.

11. Duggan ST. Pitavastatin: a review of its use in the management of hypercholesterolemia or mixed dyslipidaemia. Drugs. 2012;72(4):565-84.

12. Suzuki M, Iwasaki H, Fujikawa Y, Kitahara M, Sakashita M, Sakoda R. Synthesis and biological evaluations of quinoline-based HMG-CoA reductase inhibitors. Bioorg Med Chem. 2001;9(10):2727-43.

13. Aoki T, Nishimura H, Nakagawa S, Kojima J, Suzuki $\mathrm{H}$, Tamaki $\mathrm{T}$, et al. Pharmacological profile of a novel synthetic inhibitor of 3-hydroxy-3methylglutaryl- coenzyme A reductase. Arzneimittelforschung. 1997;47(8):904-9.

14. Morikawa S, Umetani M, Nakagawa S, Yamazaki H, Suganami H, Inoue $\mathrm{K}$, et al. Relative induction of mRNA for HMG CoA reductase and LDL receptor by five different HMG-CoA reductase inhibitors in cultured human cells. J Atheroscler Thromb. 2000;7(3):138-44.

15. Corsini A, Ceska R. Drug-drug interactions with statins: will pitavastatin overcome the statins achilles heel? Curr Med Res Opin. 2011;27(8):1551-62. 
16. Ando H, Tsuruoka S, Yanagihara H, Sugimoto K, Miyata M, Yamazoe Y, et al. Effects of grapefruit juice on the pharmacokinetics of pitavastatin and atorvastatin. Br J Clin Pharmacol. 2005;60(5):494-7.

17. Saito Y. Critical appraisal of the role of pitavastatin in treating dyslipidemias and achieving lipid goals. Vasc Health Risk Manag. 2009;5:921-36.

18. Chong PH, Seeger JD. Atorvastatin calcium: an addition to HMG-CoA reductase inhibitors pharmacotherapy. 1997; 17(6):1157-77.

19. Athyros VG, Tziomalos K, Karagiannis A, Mikhailidis DP. Atorvastatin: safety and tolerability. Expert Opin Drug Saf. 2010;9(4):667-74.

20. Adams SP, Tsang M, Wright JM. Lipid lowering efficacy of atorvastatin. Cochrane Database of Systematic Reviews. Cochrane Database Syst Rev. 2015;3:CD008226.

21. Phatak H, Wentworth C, Sazonov V, Burke T. Prevalence and predictors of lipid abnormalities in patients treated with statins in the UK general practice. Atherosclerosis. 2009;202(1):225-33.

22. Ferrières J, Gousse ET, Fabry C, Hermans MP; French CEPHEUS investigators. Assessment of lipidlowering treatment in France-the CEPHEUS study. Arch Cardiovasc Dis. 2008;101(9):557-63.

23. Ruiz FJG, Ibáñez AM, Jiménez FP, Pintó X, Nocea G, Ahumada C, et al. Current lipid management and low cholesterol goal attainment in common daily practice in Spain. The REALITY Study. Pharmacoeconomics. 2004;22(3):1-12.

24. Hermans MP, Cabezas MC, Strandberg T, Ferrières J, Feely J, Elisaf M, et al. Centralized Pan-European survey on the under treatment of hypercholesterolaemia (CEPHEUS): overall findings from eight countries (CEPHEUS). Curr Med Res Opin. 2010;26(2):445-54.

25. Wilson PWF, D'Agostino RB, Levy D, Belanger AM, Silbershatz H, Kannel WB. Prediction of coronary heart disease using risk factor categories. Circulation. 1998;97(18):1837-47.

26. Stamler J, Wentworth D, Neaton JD. Is relationship between serum cholesterol and risk of premature death from coronary heart disease continuous and graded? Findings in 356,222 primary screenees of the Multiple Risk Factor Intervention Trial (MRFIT). JAMA. 1986;256(20):2823-8.

27. Lipid research clinics program. The lipid research clinics coronary primary prevention trial results. I: Reduction in the incidence of coronary heart disease. JAMA. 1984;251(3):351-64.

28. Lipid research clinics program. The lipid research clinics coronary primary prevention trial results. II: The relationship of reduction in incidence of coronary heart disease to cholesterol lowering. JAMA. 1984;251(3):365-74.

29. Rossouw JE, Lewis B, Rifkind BM. The value of lowering cholesterol after myocardial infarction. N Engl J Med. 1990;323(16):1112-9.

30. Pekkanen J, Linn S, Heiss G, Suchindran CM, Leon A, Rifkind BM, et al. Ten-year mortality from cardiovascular disease in relation to cholesterol level among men with and without preexisting cardiovascular disease. $\mathrm{N}$ Engl J Med. 1990;322(24):1700-7.

31. Toth PP. Drug treatment of hyperlipidaemia: a guide to the rational use of lipid-lowering drugs. Drugs. 2010;70(11):1363-79.

32. Davidson MH, Toth PP. Comparative effects of lipid lowering therapies. Prog Cardiovasc Dis. 2004;47(2):73-104.

33. Downs JR, Clearfield M, Weis S, Whitney E, Shapiro DR, Beere PA, et al. Primary prevention of acute coronary events with lovastatin in men and women with average cholesterol levels: results of AFCAPS/TexCAPS. Air Force/Texas Coronary Atherosclerosis Prevention Study. JAMA. 1998;279(20):1615-22.

34. Scandinavian simvastatin survival study group. Randomised trial of cholesterol lowering in 4444 patients with coronary heart disease: the scandinavian simvastatin survival study (4S). Lancet. 1994;344(8934):1383-9.

35. LaRosa JC, He J, Vupputuri S. Effect of statins on risk of coronary disease; a meta-analysis of randomized controlled trials. JAMA. 1999;282(24):2340-6.

36. Sever PS, Dahlöf B, Poulter NR, Wedel H, Beevers G, Caulfield M, et al. Prevention of coronary and stroke events with Atorvastatin in hypertensive patients who have average or lower-than-average cholesterol concentrations, in the anglo-scandinavian cardiac outcomes trial-lipid lowering arm (ASCOTLLA): a multicentre randomised controlled trial. Lancet. 2003;361(9364):1149-58.

37. Gumprecht J, Gosho M, Budinski D, Hounslow N. Comparative long-term efficacy and tolerability of pitavastatin $4 \mathrm{mg}$ and atorvastatin $20-40 \mathrm{mg}$ in patients with type 2 diabetes mellitus and combined (mixed) dyslipidaemia. Diabetes Obes Metab. 2011;13(11):1047-55.

38. Ose L, Budinski D, Hounslow N, Arneson V. Comparison of pitavastatin with simvastatin in primary hypercholesterolaemia or combined dyslipidaemia. Curr Med Res Opin. 2009;25(11):2755-64.

39. Eriksson M, Budinski D, Hounslow N. Comparative efficacy of pitavastatin and simvastatin in high-risk patients: a randomized controlled trial. Adv Ther. 2011;28(9):811-23.

40. Budinski D, Arneson V, Hounslow N, Gratsiansky N. Pitavastatin compared with atorvastatin in primary hypercholesterolemia or combined dyslipidemia. Clin Lipidol. 2009;4(3):291-302.

41. Kawashiri MA, Nohara A, Tada H, Mori M, Tsuchida M, Katsuda S, et al. Comparison of effects of pitavastatin and atorvastatin on plasma coenzyme Q10 in heterozygous familial hypercholesterolemia: results from a crossover study. Clin Pharmacol Ther. 2008;83(5):731-9. 
42. Nawrocki JW, Weiss SR, Davidson HM, Sprecher DL, Schwartz SL, Lupien PJ, et al. Reduction of LDL cholesterol by $25 \%$ to $60 \%$ in patients with primary hypercholesterolemia by atorvastatin, a new hmgCoa reductase inhibitor. Arterioscler Thromb Vasc Biol. 1995;15:678.

43. Schrott H, Fereshetian AG, Knopp RH, Bays H, Jones PH, Littlejohn TW, et al. A multicenter, placebo-controlled, dose-ranging study of atorvastatin. J Cardiovasc Pharmacol Ther. 1998;3(2):119-24.

44. Jones P, Kafonek S, Laurora I, Hunninghake D. Comparative dose efficacy study of atorvastatin versus simvastatin, pravastatin, lovastatin, and fluvastatin in patients with hypercholesterolemia (the CURVES study). Am J Cardiol. 1998;81(5):582-7.

45. Andrews TC, Ballantyne CM, Hsia JA, Kramer JH. Achieving and maintaining national cholesterol education program low-density lipoprotein cholesterol goals with five statins. Am J Med. 2001;111(3):185-91.

46. Kurogi K, Sugiyama S, Sakamoto K, Tayama S, Nakamura S, Biwa $\mathrm{T}$, et al; Comparison of pitavastatin with atorvastatin in increasing HDLcholesterol and adiponectin in patients with dyslipidemia and coronary artery disease: The COMPACT-CAD study. Journal of Cardiology. 2013;62:87-94.

Cite this article as: Patil CY, Baig MS, Doifode SM. Assessing the efficacy and safety of pitavastatin compared to atorvastatin in dyslipidemic patients: a double blind randomized controlled trial. Int J Basic Clin Pharmacol 2016;5:834-40. 